\title{
Differential regulation of apical and basal iodide transporters in the thyroid by thyroglobulin
}

\author{
Koichi Suzuki and Leonard D Kohn \\ Cell Regulation Section, Metabolic Diseases Branch, National Institute of Diabetes and Digestive and Kidney Diseases, National Institutes of Health, Bethesda, \\ Maryland 20892, USA \\ (Requests for offprints should be addressed to K Suzuki; Email: koichis@nih.go.jp.) \\ (K Suzuki is now at Department of Bioregulation, Leprosy Research Center, National Institute of Infectious Diseases, 4-2-1 Aoba-cho, Higashimurayama, \\ Tokyo 189-0002, Japan) \\ (L D Kohn is now at Ohio University School of Osteopathic Medicine and Edison Biotechnology Institute, Athens, Ohio 45701, USA)
}

\begin{abstract}
We have shown that thyroglobulin $(\mathrm{Tg})$ is a potent autocrine regulator of thyroid-specific gene expression, and proposed that the accumulated follicular Tg within the colloid is a major factor in determining follicular function. In the present report, we examined the effect of $\mathrm{Tg}$ on the action of TSH/cAMP and iodine with special focus on the regulation of basolateral and apical iodide transporters; the sodium/iodide symporter (NIS) and the
\end{abstract}

pendred syndrome gene (PDS) by Tg. We show that expression of NIS and PDS are differentially regulated by $\mathrm{Tg}$ concentration and exposure time. In addition, we found that PDS gene was induced by TSH/cAMP and iodide in the presence of $\mathrm{Tg}$. Based on these results, we propose a model for the physiological turnover of follicular function that is dynamically regulated by $\mathrm{Tg}$.

Journal of Endocrinology (2006) 189, 247-255

\section{Introduction}

Follicular structures are the minimal functional units of the thyroid, and are the sites of thyroid hormone biosynthesis. However, the function of each follicle is heterogeneous and not synchronized. Indeed, significant follicular variability exists, not only in shape, size and colloid density, but also in the ability to accumulate iodide, diffusion of iodinated thyroglobulin $(\mathrm{Tg})$ within the follicular lumen (Gerber et al. 1985, 1986, Suzuki et al. 1999c), levels of Tg and thyroid hormones within the follicles (Suzuki et al. 1999a, 1999c), and even in expression of thyroid transcription factor (TTF-1), an essential transcription factor (Suzuki et al. 1999a, 1999b). In addition, heterogeneity in the expression of other proteins and cell growth has been noted under various experimental conditions (Yamamoto et al. 1988, Kawaoi et al. 1991, Suzuki et al. 1991, 1992) and in human goiters (Peter et al. 1985, Studer et al. 1989).

Biosynthesis of thyroid hormones depends on the expression and function of several thyroid-specific genes, including $\mathrm{Tg}$, thyroperoxidase (TPO), sodium/iodide symporter (NIS), pendred syndrome gene (PDS), and thyrotropin receptor (TSHR). Dietary iodide is taken up through NIS expressed on the basolateral membrane of the thyroid (Dai et al. 1996, Caillou et al. 1998, Jhiang et al. 1998), and secreted into the follicular lumen via the apical iodide transporter pendrin (Everett et al. 1997, Royaux et al. 2000, Yoshida et al. 2002, Gillam et al. 2004,
Yoshida et al. 2004) and an iodide channel (Golstein et al. 1992, Nilsson et al. 1992, Yoshida et al. 1997, 1998).

We have shown that $\mathrm{Tg}$, the major product of the thyroid follicular cell, is a potent suppressor of thyroidspecific gene expression, and that this action of $\mathrm{Tg}$ overcomes TSH-mediated effects. Thus, it appears that Tg is a feedback suppressor of its own expression, as well as of TPO, NIS and TSHR, through suppression of specific transcription factors, such as TTF-1, TTF-2 and Pax-8 (Suzuki et al. 1998b, 1999b). Suppression of NIS expression by $\mathrm{Tg}$ decreases iodide uptake in vitro, while the accumulation of $\mathrm{Tg}$ in the follicular lumen correlates with low iodide uptake in vivo (Suzuki et al. 1999c). Tg not only exhibits suppressive activity, but increases mRNA levels and promoter activity of major histocompatibility complex class I genes (Suzuki et al. 1998b), and significantly induces PDS expression (Royaux et al. 2000). Final Tg concentrations of 1 to $10 \mathrm{mg} / \mathrm{ml}$ in cell culture medium were effective in experiments using rat thyroid FRTL-5 cells in vitro (Suzuki et al. 1998b, 1999b, 1999c). This is thought to represent the lower range of $\mathrm{Tg}$ concentration within the normal thyroid follicle, which varies from $0 \cdot 1 \mathrm{mg} / \mathrm{ml}$ up to $250 \mathrm{mg} / \mathrm{ml}$ depending on the method used for measurement (i.e. aspiration biopsy or micropuncture of a single follicle). The relatively large range in estimates of physiological $\mathrm{Tg}$ concentration is most probably the result of the significant functional heterogeneity between follicles (Hayden et al. 1970, Smeds 1972, Salabe et al. 1996). 
It is interesting to note that Tg suppresses the basolateral iodide transporter NIS, but induces the apical transporter, pendrin (Suzuki et al. 1999c, Royaux et al. 2000), suggesting differential regulation of the basal and apical iodide transporters by Tg. Furthermore, although TSH/cAMP is the strongest inducer of NIS (Kogai et al. 1997), there was no detectable effect of TSH on PDS gene expression (Royaux et al. 2000). In addition, iodide is known to down-regulate iodide uptake and NIS mRNA levels even in cultured thyroid cells (Eng et al. 1999), while the effect of iodide on PDS gene expression is not known. Therefore, in the present study, we tried to clarify the differential effects of Tg on NIS and PDS expression, as well as the role of $\mathrm{Tg}$ on the action of TSH/cAMP and iodide to regulate the expression of these genes.

\section{Materials and Methods}

Cells

An F-1 subclone of rat FRTL-5 thyroid cells (ATCC CRL8305) was provided by the Interthyr Research Foundation, Baltimore, MD, USA. Cells were grown in Coon's modified F-12 medium (Sigma Chemical Co) containing 5\% heat-treated, mycoplasma-free calf serum (GIBCO Laboratories Life Technologies), $1 \mathrm{mM}$ nonessential amino acids (GIBCO), and supplemented with six hormones or growth factors (termed $6 \mathrm{H}$ ) that included bovine TSH $\left(1 \times 10^{-10} \mathrm{M}\right)$, insulin $(10 \mu \mathrm{g} / \mathrm{ml})$, cortisol $(0.4 \mathrm{ng} / \mathrm{ml})$, transferrin $(5 \mu \mathrm{g} / \mathrm{ml})$, glycyl-L-histidyl-Llysine acetate $(10 \mathrm{ng} / \mathrm{ml})$, and somatostatin $(10 \mathrm{ng} / \mathrm{ml})$. Bovine $\mathrm{Tg}$ was added directly to the culture medium as described previously (Royaux et al. 2000, Suzuki et al. 1998c, 1999c).

\section{RNA isolation and Northern blot analysis}

Total RNA isolation and Northern blot analysis were performed as previously described (Suzuki et al. 1998b, 1998c). RNA was prepared using an RNeasy Mini Kit (Qiagen). Cells were cultured in $10 \mathrm{~cm}$ dishes, washed with PBS, recovered with $600 \mu l$ lysis solution, and passed through a QIAshredder (Qiagen). After the addition of $600 \mu 170 \%$ ethanol, the mixture was passed through a spin column, washed with $600 \mu \mathrm{l}$ RW1 wash solution, and twice with $500 \mu \mathrm{l}$ RPE wash solution. RNA was eluted with $30 \mu \mathrm{l}$ of diethylpyrocarbonate-treated water. RNA samples were electrophoresed on denaturing agarose gels and capillary blotted onto Nytran nylon membranes $(11 \times 14 \mathrm{~cm}$, Schleicher \& Schuell, Keene, NH, USA) using a Turboblotter (Schleicher \& Schuell). Hybridization was performed after u.v. cross-linking. Probes were labeled with ${ }^{32} \mathrm{P}$-dCTP using a Ladderman Labeling Kit (PanVera, Madison, WI, USA) in the presence of random primer, dNTP, and Bca DNA polymerase. Radiolabeled probe $\left(1 \times 10^{7}\right.$ c.p.m. $)$ was premixed with $100 \mu$ l sonicated salmon sperm DNA (Stratagene, La Jolla, CA, USA), heated at $94^{\circ} \mathrm{C}$ for $5 \mathrm{~min}$, chilled on ice, and added to membranes prehybridized with $10 \mathrm{ml}$ QuickHyb Hybridization Solution (Stratagene) for $1 \mathrm{~h}$ at $68^{\circ} \mathrm{C}$. After hybridization for $3 \mathrm{~h}$, membranes were washed in 4 $\times$ SSPE, $0.5 \% \operatorname{SDS}$ for $30 \mathrm{~min}$ at $37{ }^{\circ} \mathrm{C} ; 2 \times$ SSPE, $0 \cdot 1 \%$ SDS for $20 \mathrm{~min}$ at $65^{\circ} \mathrm{C}$; and $1 \times \operatorname{SSPE}, 0 \cdot 1 \%$ SDS for $20 \mathrm{~min}$ at $65^{\circ} \mathrm{C}$. Membranes were reprobed after incubation in $50 \%$ formamide, $50 \mathrm{mM}$ Tris-Cl, $\mathrm{pH} 8.0$, and $10 \% \mathrm{SDS}$, for 1 to $2 \mathrm{~h}$ at $65{ }^{\circ} \mathrm{C}$.

\section{Immunohistochemistry}

Rat thyroid tissues were fixed with neutral-buffered formalin and immunostained as previously described (Suzuki et al. 1991, 1992, 1998a, 1998c). Briefly, deparaffinized and rehydrated sections were treated with 3\% $\mathrm{H}_{2} \mathrm{O}_{2}$ for $10 \mathrm{~min}$ at room temperature, washed in PBS, incubated with $10 \%$ normal goat serum, and incubated with rabbit anti-rat Tg antibody (a gift from Dr A Kawaoi, Yamanashi Medical University, Yamanashi, Japan) diluted 1:1000. After three 5-min washes in PBS, sections were exposed to horseradish peroxidase-labeled swine antirabbit IgG antibody (1:100 dilution; DAKO) for $1 \mathrm{~h}$. Sections were then rinsed in PBS for 5 min three times, and peroxidase activity detected with 3,3'-diaminobenzidine solution containing $0 \cdot 003 \% \mathrm{H}_{2} \mathrm{O}_{2}$. Cell nuclei were lightly counter-stained with hematoxylin.

\section{Others}

Highly purified bovine TSH was obtained from the hormone distribution program of the National Institute of Diabetes and Digestive and Kidney Diseases, National Institutes of Health (NIDDK-bTSH; $30 \mathrm{U} / \mathrm{mg}$ ). Bovine $\mathrm{Tg}, 8$-bromo cAMP and forskolin were obtained from the Sigma Chemical Co. Bovine follicular 19S Tg prepared by salt extraction and agarose chromatography were used in some experiments and showed essentially the same results (Ulianich et al. 1999). All experiments were repeated at least three times using different batches of cells.

\section{Results}

Synergistic effect of TSH/cAMP and follicular $\mathrm{Tg}$ on induction of PDS gene expression

In order to study the effects of $\mathrm{Tg}$ on TSH action, we treated FRTL-5 cells with TSH $\left(1 \times 10^{-10} \mathrm{M}\right)$ in the presence or absence of $1 \mathrm{mg} / \mathrm{ml} \mathrm{Tg}$ for $24 \mathrm{~h}$. As previously reported (Suzuki et al. 1999c, Royaux et al. 2000), TSH alone induced NIS expression, but had no effect on PDS expression (Fig. 1A, lanes 2). Although Tg alone induces PDS expression, it was further enhanced when both TSH 


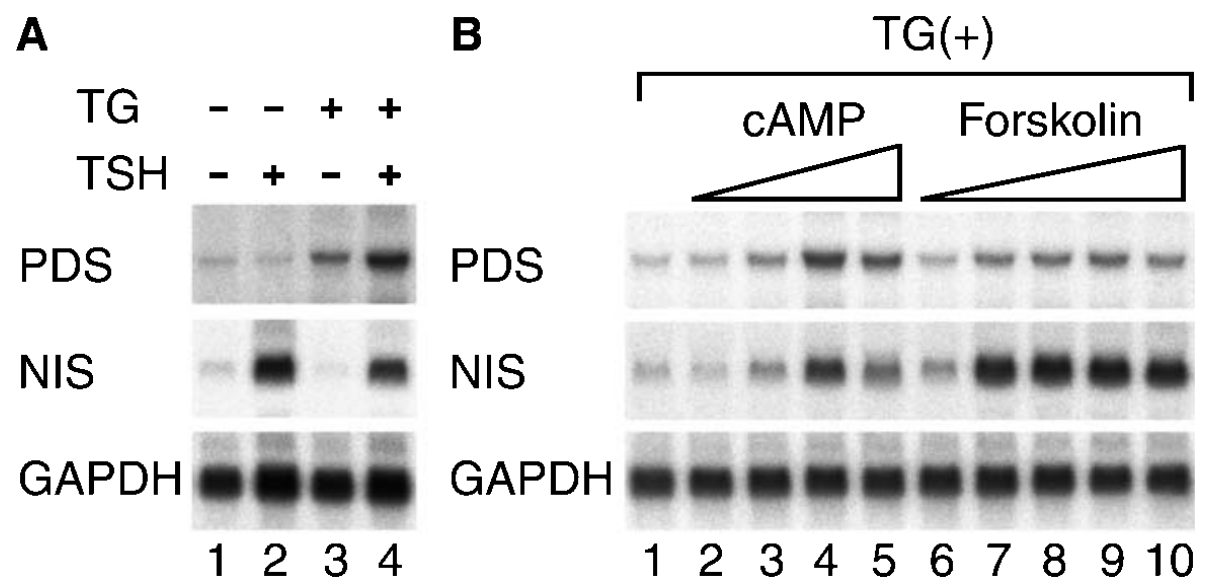

Figure 1 Coordinate regulation of PDS and NIS mRNA levels by TSH/cAMP and Tg. Either TSH $\left(1 \times 10^{-10} \mathrm{M}\right)$ or $\mathrm{Tg}(1 \mathrm{mg} / \mathrm{ml})$ alone or both together were added to cultures of FRTL-5 cells maintained without TSH for 5 days (A). Cyclic AMP (8-bromo CAMP) at final concentrations of $0 \cdot 01,0 \cdot 1,1$ and $10 \mathrm{mM}$, and forskolin at final concentrations of $0 \cdot 05,0 \cdot 5,5,10$ and $50 \mu \mathrm{M}$ were added to the TSH-depleted FRTL-5 cells with $1 \mathrm{mg} / \mathrm{ml}$ of $\mathrm{Tg}(\mathrm{B})$. In both cases, cells were further maintained for $24 \mathrm{~h}$ and Northern blot analysis performed as described in the Materials and Methods section.

and Tg were added (Fig. 1A, lane 4), suggesting that TSH and Tg acted synergistically on PDS expression.

Such a synergistic effect of TSH was reproduced by cAMP or forskolin. Thus, when cAMP or forskolin were added in the presence of $1 \mathrm{mg} / \mathrm{ml}$ of Tg, PDS expression was significantly enhanced (Fig. 1B). These results suggest that the ability of low $\mathrm{Tg}$ concentrations to induce PDS expression was amplified in the presence of a TSH/cAMP signal. The same concentrations of cAMP or forskolin alone induced NIS, but not PDS expression (partly shown in Fig. 2B). This is relevant to the absence of PDS induction by TSH as shown in Fig. 1A.

Expression of PDS and NIS are differently regulated by $\mathrm{Tg}$ and the TSH/CAMP signal

In order to study the kinetics of PDS and NIS gene expression, FRTL-5 cells were maintained without TSH for five days, then treated with $\mathrm{Tg}$, forskolin or both $\mathrm{Tg}$ and forskolin. Northern blot analysis was performed at various time points after treatment. In the absence of TSH/cAMP stimulation, Tg induced PDS mRNA in $6 \mathrm{~h}$ and suppressed NIS mRNA in $3 \mathrm{~h}$ (Fig. 2A). PDS expression was only transient and had decreased by $12 \mathrm{~h}$, while NIS expression was suppressed between 3 and $12 \mathrm{~h}$ (Fig. 2A). Forskolin alone significantly increased NIS expression at $12 \mathrm{~h}$, but had no effect on PDS expression (Fig. 2B), which is similar to that observed for TSH (Fig. 1A, lane 2). Interestingly, when both forskolin and $\mathrm{Tg}$ were added, PDS expression was prolonged beyond $72 \mathrm{~h}$ and the time of maximum expression shifted to $48 \mathrm{~h}$ post-stimulation (Fig. 2C). Induction of NIS mRNA was weaker than observed using forskolin alone, suggesting that NIS mRNA levels represented the sum of forskolininduction and $\mathrm{Tg}$ suppression (Fig. 2C). These results suggest that TSH/cAMP significantly modulated the ability of follicular Tg to induce PDS expression.

Since TSH constantly exists in vivo situation, we then studied the effect of low $\mathrm{Tg}$ concentrations on cells chronically treated with TSH. FRTL-5 cells maintained with TSH were treated with $1 \mathrm{mg} / \mathrm{ml} \mathrm{Tg}$, and RNA isolated at various time points. PDS mRNA was induced from $3 \mathrm{~h}$ after $\mathrm{Tg}$ stimulation, peaked at $24 \mathrm{~h}$, and then decreased (Fig. 3A). In contrast, NIS mRNA, maximally induced by chronic TSH stimulation, was gradually decreased by $\mathrm{Tg}$ treatment (Fig. 3A) as previously reported (Suzuki et al. 1999c). When Tg was removed from the culture medium, PDS mRNA levels significantly decreased in $12 \mathrm{~h}$ (Fig. 3B), while NIS expression was increased by $24 \mathrm{~h}$ (Fig. 3B).

These results suggest that the expression of NIS and PDS, two major transporters responsible for the influx and efflux of iodide, respectively, are differentially regulated by $\mathrm{Tg}$ and TSH/cAMP. Significant changes in PDS expression compared with NIS expression under constant TSH stimulation further suggests that regulation of PDS expression may be a more important factor than NIS expression in determining the rate of iodine transport into follicular space.

\section{Iodide induction of PDS and suppression of NIS expression}

Differential regulation of NIS and PDS by changes in follicular $\mathrm{Tg}$ concentration further suggests that iodide concentration within follicular cells may be considerably different in these situations. Thus, in a follicle where $\mathrm{Tg}$ 


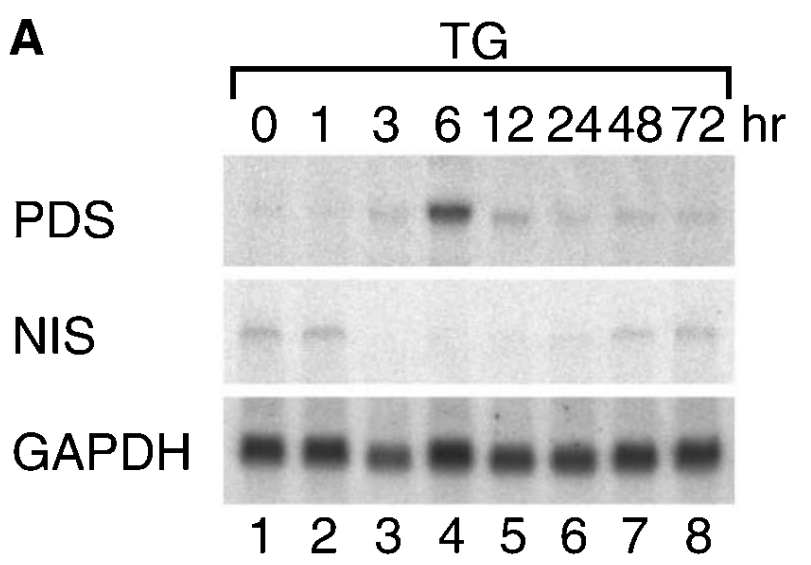

B

PDS

NIS

GAPDH

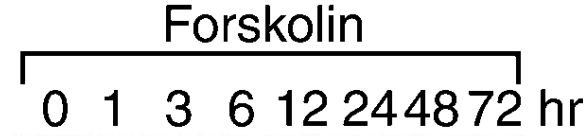

C

\section{PDS}

NIS

GAPDH
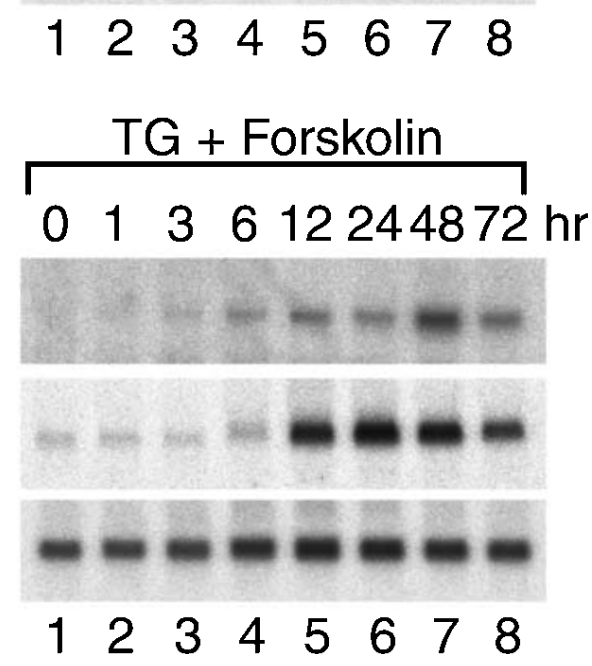

Figure 2 Time-dependent regulation of PDS and NIS mRNA levels by cAMP signaling and Tg. TSH was depleted from the culture medium of FRTL-5 cells at $40-50 \%$ confluency, maintained for 5 days, then $1 \mathrm{mg} / \mathrm{ml} \mathrm{Tg}(\mathrm{A}), 10 \mu \mathrm{M}$ forskolin (B) or both Tg and forskolin (C) added. Cells were further maintained for 1 to $72 \mathrm{~h}$ and Northern blot analysis performed.

has not accumulated but is exposed to constant TSH stimulation (as shown in Fig. 3A, lane 1), iodide may accumulate within the thyrocyte by maximum uptake through NIS, but minimal efflux due to the lack of PDS expression. As a result, iodine concentrations within the follicular cell may become much higher than extracellular concentration. In fact, we have shown that NIS can still transport iodide even when intracellular iodide concentration reaches $2 \mathrm{mM}$ (Yoshida et al. 2002). Therefore, although relatively low concentrations of iodide had no direct effect on PDS expression (Royaux et al. 2000), the effect of higher concentration of iodide was tested in the presence of $\mathrm{Tg}$ to evaluate possible effects on NIS and PDS expression.

When $\mathrm{NaI}$ was added $(5 \mathrm{mM})$ to the culture medium of FRTL-5 cells for $24 \mathrm{~h}$ in the presence of TSH $\left(1 \times 10^{-10} \mathrm{M}\right)$ but not $\mathrm{Tg}(1.0 \mathrm{mg} / \mathrm{ml})$, no change was observed in PDS expression (Fig. 4A, lane 2 vs lane 1). However, when $\mathrm{NaI}$ was added with $\mathrm{Tg}$, follicular $\mathrm{Tg}-$ induced PDS expression was further enhanced from 6 to $12 \mathrm{~h}$, whereas NIS expression was suppressed in $12 \mathrm{~h}$ (Fig. 4B). These results suggest that accumulation of iodide also regulates PDS and NIS expression in the presence of TSH and Tg.

Tg-mediated regulation of gene expression and $\mathrm{Tg}$ synthesis in vivo

As previously reported, there was an inverse correlation between the accumulation of follicular Tg and uptake of radio-iodine in vivo (Suzuki et al. 1999c). This evidence prompted us to investigate the relationship between follicular Tg accumulation and new Tg synthesis within follicular epithelium. Tg immunostaining showed variable intensity within the colloid as well as in the cytoplasm of follicular cells (Fig. 5A). Colloid staining represented accumulated $\mathrm{Tg}$, while cytoplasmic staining reflected newly synthesized $\mathrm{Tg}$ in the Golgi apparatus and rER rather than reabsorbed $\mathrm{Tg}$ in the lysozomes, as confirmed by immunoelectron microscopy on various aspects of follicular function (Yamamoto et al. 1997, Yi et al. 1997, Suzuki et al. 1999a). Fig. 5A clearly shows that in a follicle with poor $\mathrm{Tg}$ accumulation (marked as $\mathrm{I}$ ), active $\mathrm{Tg}$ synthesis occurs within the cytoplasm (as arrowed). In contrast, in a follicle where a large amount of $\mathrm{Tg}$ has accumulated within the follicular lumen (marked as III), Tg staining within the cytoplasm was significantly reduced (as indicated by arrowheads). In a follicle showing intermediate $\mathrm{Tg}$ accumulation (marked as II), the intensity of cytoplasmic staining of Tg was between I and III. Thus, there was an inverse correlation between the accumulation of follicular $\mathrm{Tg}$ and new synthesis of $\mathrm{Tg}$ within follicular cells.

These three follicle types may represent the differential effects of accumulated follicular Tg on thyroid hormone synthesis. This is demonstrated in differentially regulated gene expression by follicular Tg. Thus, in the absence of $\mathrm{Tg}$, gene expression of NIS, Tg itself, TPO and vascular endothelial growth factor/vascular permeability (VEGF/ VPF) is maximal (Fig. 5B, i). With low concentrations of 


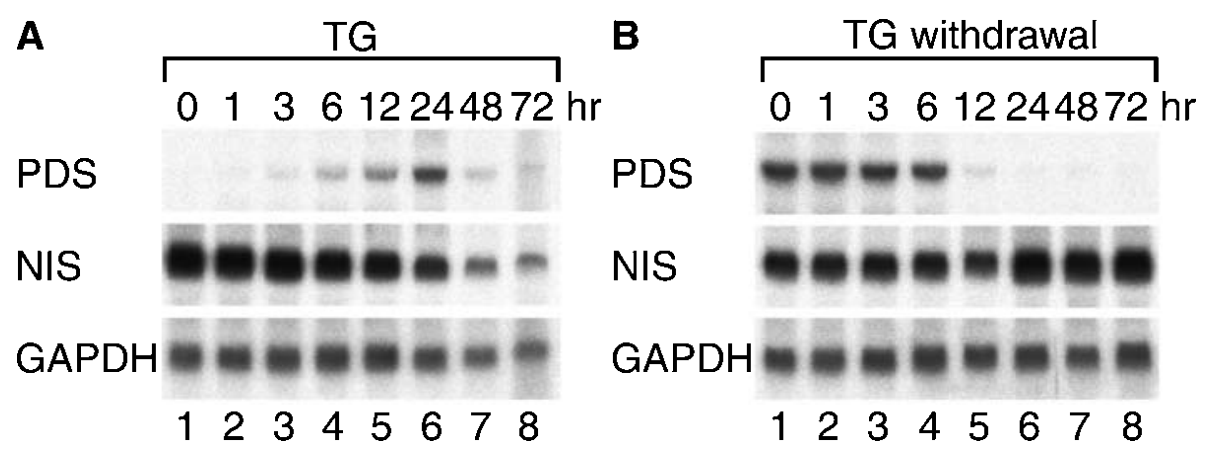

Figure 3 Effect of adding or withdrawing Tg under chronic TSH/CAMP stimulation. FRTL-5 cells at $40-50 \%$ confluency were maintained with $1 \times 10^{-10} \mathrm{M} \mathrm{TSH}$, then $1 \mathrm{mg} / \mathrm{ml} \mathrm{Tg}$ was added and incubated for a further 1 to $72 \mathrm{~h}(\mathrm{~A})$. In a different experiment, cells were maintained under the same conditions for $24 \mathrm{~h}$ to induce maximal PDS expression, after which Tg was washed out from the culture medium and grown in normal medium with TSH for 1 to $72 \mathrm{~h}$.

follicular Tg, PDS gene expression is weakly induced, but expression of the other genes is still maintained (Fig. 5B, ii). However, under higher concentrations of $\mathrm{Tg}$, the expression of genes necessary for iodide transport and hormone synthesis is suppressed (Fig. 5B, iii). These results support the in vivo evidence shown in Fig. 5A.

\section{Discussion}

$\mathrm{TSH}$, iodide and $\mathrm{Tg}$ are the essential regulators of the thyroid

We have shown in previous studies that follicular Tg is a potent regulator of follicular function and mediates the transcriptional suppression of genes essential for iodide transport and hormone synthesis (Suzuki et al. 1998b, $1999 b, 1999 c)$. We have also shown that follicular Tg is a major inducer of PDS expression in rat FRTL-5 thyroid cells (Royaux et al. 2000). In the present study, we demonstrated that PDS expression is additionally regulated by TSH and iodide in the presence of Tg. These findings support a concept that TSH, iodide and Tg are the major regulators of follicular function. However, in the in vivo situation, where serum TSH levels are relatively constant, differences in follicular Tg content may act as the dynamic regulator of follicular function. Furthermore, although serum iodide concentration appear not to be significant to regulate follicular function and thyroid gene expression,

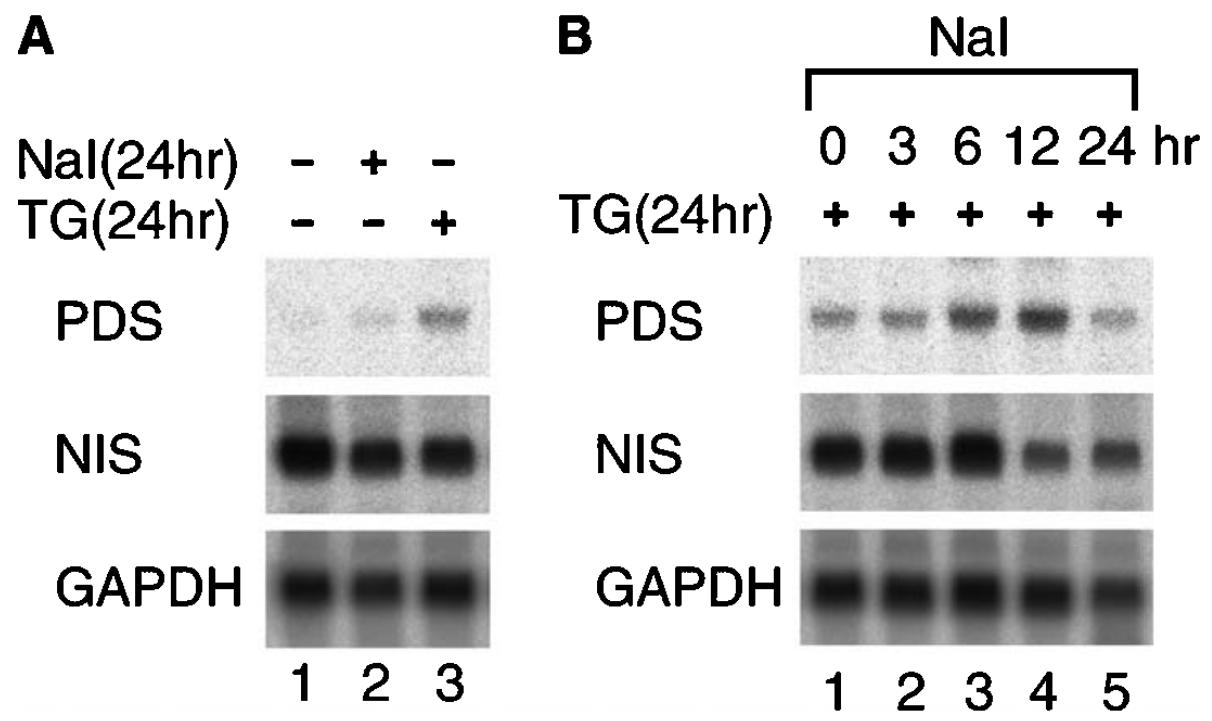

Figure 4 Additive effect of iodide and Tg in the induction of PDS mRNA. FRTL-5 cells were treated with either $\mathrm{Nal}(5 \mathrm{mM})$ or $\mathrm{Tg}(1.0 \mathrm{mg} / \mathrm{ml})$ for $24 \mathrm{~h}(\mathrm{~A})$, or Nal plus Tg added to cells pre-treated with $\mathrm{Tg}$ for $24 \mathrm{~h}$ and further maintained for 3 to $24 \mathrm{~h}$ (B). Both experiments were performed in the presence of TSH $\left(1 \times 10^{-10} \mathrm{M}\right)$. 

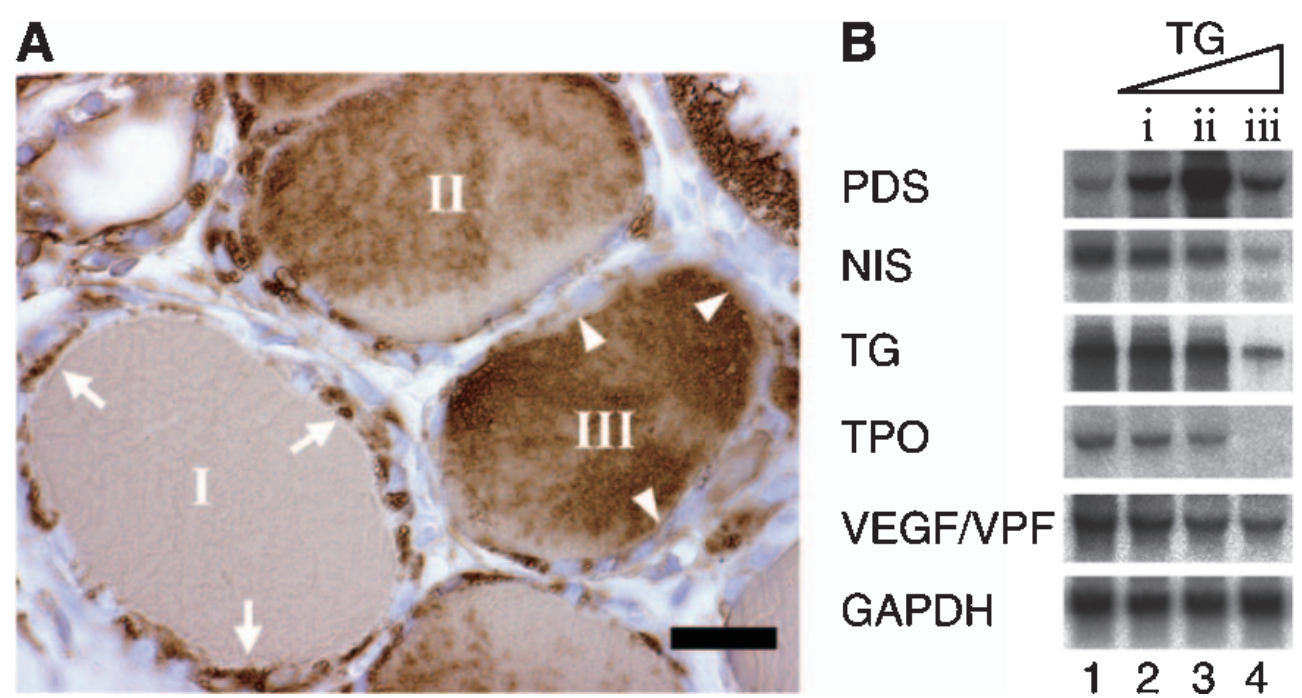

Figure 5 Immunohistochemical demonstration of Tg with three representative follicles shown as I, II and III (A). A follicle with weak follicular Tg staining, but strong cytoplasmic Tg staining marked as I; a follicle with strong follicular Tg staining, but weak cytoplasmic staining marked as III; and an intermediate follicle marked as II. Perinuclear Tg staining in the follicular cells indicated by arrows represents newly synthesized $\mathrm{Tg}$ situated in the Golgi apparatus and rER rather than reabsorbed Tg in lysozomes, as demonstrated by immunoelectron microscopy (Suzuki et al. 1999a, Yamamoto et al. 1997, Yi et al. 1997). In B, changes in mRNA levels of thyroid genes in FRTL-5 cells by gradient of Tg concentration (i, ii and iii) are shown. Increasing amounts of $\operatorname{Tg}(0 \cdot 1,1$ and $10 \mathrm{mg} / \mathrm{ml})$ were added to the culture medium of FRTL-5 cells maintained with $\mathrm{TSH}$, and incubated for a further $24 \mathrm{~h}$.

high expression of NIS, but not PDS in the presence of low Tg concentration, will result in high levels of iodide accumulation within the thyrocyte that is enough to affect gene expression. Our results also showed differential regulation of PDS expression compared with other important thyroid genes, e.g. NIS, Tg, TPO, TSHR and VEGF/VPF. Thus, while all the other genes were down regulated by Tg, PDS was induced. Therefore, changes in PDS expression may have a unique role in the regulation of follicular function.

\section{Heterogeneous follicles represent different functional phases}

Even though the role of follicular Tg content on regulation of gene expression is well established, the mechanism by which follicular heterogeneity is generated remains unknown. There are several possibilities that may explain the nature of follicular heterogeneity. Some evidence suggests that individual thyrocytes within the follicle are not functionally uniform. Using chimeric mice, it has been shown that epithelial cells surrounding a follicle do not originate from a single cell, but are mosaic (Feder 1976, Thomas et al. 1989). It is known that cloned thyroid cells show significant variability in growth and function in culture (Huber et al. 1990). These findings suggest that the function of each follicular cell is originally heterogeneous. Furthermore, the processes of biosynthesis and secretion have their own kinetics, resulting in changes in the functional states of follicles over time. Thus, the functional difference among follicles can be explained by differences in its phases of the active cycle. This possibility is supported by the following observations. The first step in the biosynthesis of thyroid hormones involves iodide transport across the basolateral membrane. In contrast, the secretion is a process from the follicular lumen to basal membrane of follicular cells, and involves resorption, hydrolysis and secretion processes. Thus, these two pathways have opposing vectorial transport pathways through follicular cells and quite different kinetics. Wollman \& Loewenstein (1973) estimated the turnover of Tg during secretion and resorption, and found that the replacement of absorbed colloid requires 460 subapical vesicles per cell per minute. Using immunogold-labeled antibodies and immunoelectron microscopy, $\mathrm{Tg}$ content was differentially evaluated in each subcellular organelle in rat follicular cells at various time points after TSH injection (Yamamoto et al. 1997, Yi et al. 1997, Suzuki et al. 1999a). Compared with the significant $\mathrm{Tg}$ content in colloid droplets and lysozomes after short time periods, the increased $\mathrm{Tg}$ content in the rER, Golgi and subapical vesicles was insignificant even after TSH injection. These differences indicated that the new synthesis and accumulation of $\mathrm{Tg}$ within the follicular lumen were slow processes compared with the rapid removal of $\mathrm{Tg}$ from the follicular colloid. Therefore, follicular heterogeneity may be the result of the different kinetics of these processes. 

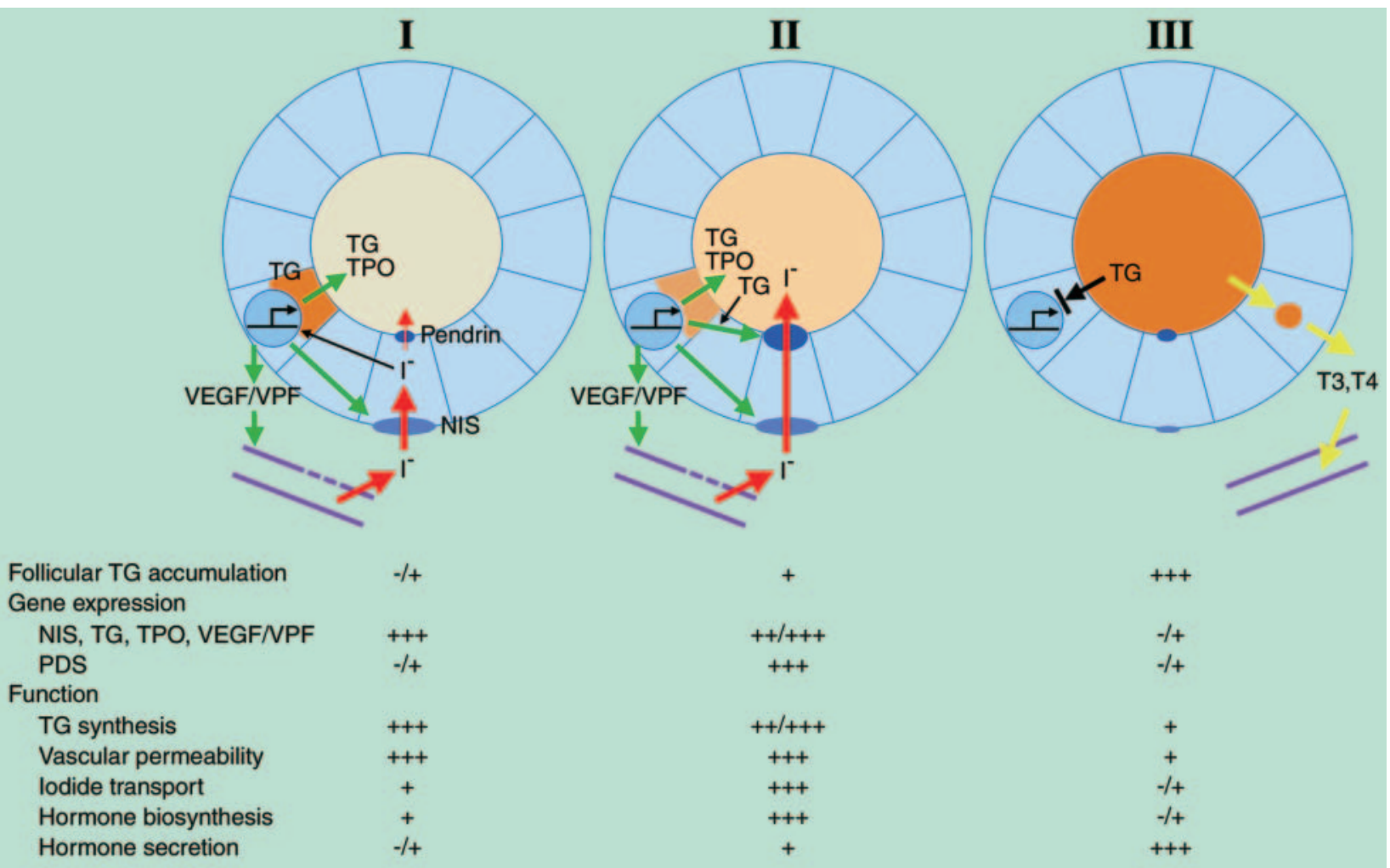

Figure 6 A modified model for the physiological regulation of follicular function. Three representative follicles (I, II and III) showing different follicular $\mathrm{Tg}$ accumulation and gene expression as indicated. Tg accumulation within the follicular lumen and cytoplasmic Tg staining in follicles I, II and III represent those shown in Fig. 5A, and levels of gene expression represent mRNA levels shown in Fig. 5B. We propose that iodinated Tg accumulates within the follicular lumen over time, from I to II, and then to III, after which reabsorption of colloid decreases Tg storage, and the cycle repeats. The effect of follicular Tg or iodide on resorption of colloid remains to be demonstrated.

\section{A model for the physiological cycle of follicular function}

Fig. 6 is the schematic representation of a concept based on the present data and the above discussion, and serves as a model for the physiological regulation of follicular function. In a follicle where Tg accumulation is minimal, gene expressions of NIS, Tg, TPO and VEGF/VPF are at their maximum under constant TSH supply (phase I). Maximum VEGF/VPF expression will increase the vascular permeability and iodide efflux into the perivascular space (Suzuki et al. 1999c). Iodide is transported into thyrocytes via NIS, but efflux is limited due to minimal pendrin expression. Under these conditions, follicular $\mathrm{Tg}$ starts to accumulate within the follicle and iodination takes place only gradually. When a low concentration of $\mathrm{Tg}$ accumulates in a follicle, maximal PDS gene expression is induced, and iodide efflux reaches maximal (phase II). In addition to $\mathrm{Tg}$, accumulated iodide within the thyrocytes also contribute to the induction of PDS shown in Fig. 4B. Expression of the other essential genes is maintained, therefore maximal hormone synthesis is achieved during this phase. When sufficient Tg accumulates within a follicle (phase III), all gene expression necessary for iodide transport and hormone biosynthesis is suppressed. The biosynthesis phase is completed, and such a follicle is ready to supply thyroid hormones by a process of resorption, degradation and secretion. Resorption of colloid occurs in greater amounts and in a shorter time than synthesis of $\operatorname{Tg}$ (Wollman \& Loewenstein 1973, Yamamoto et al. 1997, Yi et al. 1997, Suzuki et al. 1999a), so that the follicular Tg content in such a follicle decreases rapidly and the whole process of phases I, II and III is repeated. Since the kinetics of biosynthesis and resorption are different, many follicles in the same thyroid do not synchronize. Such follicles in different phases may reflect as significant heterogeneity on a tissue section. We should note that this concept applies to conditions with a normal TSH and iodide intake, and that the regulation of the studied genes may be different under conditions of a high TSH and/or iodide deficiency.

As it is not possible to observe a single follicle over time, it will be difficult to confirm this model in vivo. One of the questions that remains is the effect of $\mathrm{Tg}$ on resorption and colloid degradation. Although TSH is known to regulate 
these processes, it is unlikely that the resorption/hydrolysis activity of a follicle with low levels of $\mathrm{Tg}$ is the same as in a follicle with high $\mathrm{Tg}$ concentration. The effect of follicular $\mathrm{Tg}$ on hormone secretion remains to be determined.

\section{Acknowledgement}

The authors wish to acknowledge Ms Naoko Kudo and Emiko Moriyama for their excellent technical assistance. This work was supported in part by a Grant-in-Aid for Scientific Research (B) 15390296 from Japan Society for the Promotion of Science. The authors declare that there is no conflict of interest that would prejudice the impartiality of this scientific work.

\section{References}

Caillou B, Troalen F, Baudin E, Talbot M, Filetti S, Schlumberger M \& Bidart JM $1998 \mathrm{Na}+$ /I- symporter distribution in human thyroid tissues: an immunohistochemical study. Journal of Clinical Endocrinology and Metabolism 83 4102-4106.

Dai G, Levy O \& Carrasco N 1996 Cloning and characterization of the thyroid iodide transporter. Nature 379 458-460.

Eng PH, Cardona GR, Fang SL, Previti M, Alex S, Carrasco N, Chin WW \& Braverman LE 1999 Escape from the acute Wolff-Chaikoff effect is associated with a decrease in thyroid sodium/iodide symporter messenger ribonucleic acid and protein. Endocrinology 140 3404-3410.

Everett LA, Glaser B, Beck JC, Idol JR, Buchs A, Heyman M, Adawi F, Hazani E, Nassir E, Baxevanis AD et al. 1997 Pendred syndrome is caused by mutations in a putative sulphate transporter gene (PDS). Nature Genetics 17 411-422.

Feder N 1976 Solitary cells and enzyme exchange in tetraparental mice. Nature 263 67-69.

Gerber H, Studer H \& von Grunigen C 1985 Paradoxical effects of thyrotropin on diffusion of thyroglobulin in the colloid of rat thyroid follicles after long term thyroxine treatment. Endocrinology 116 303-310.

Gerber H, Peter HJ \& Studer H 1986 Diffusion of thyroglobulin in the follicular colloid. Endocrinology Experiments 20 23-33.

Gillam MP, Sidhaye AR, Lee EJ, Rutishauser J, Stephan CW \& Kopp P 2004 Functional characterization of pendrin in a polarized cell system. Evidence for pendrin-mediated apical iodide efflux. Journal of Biological Chemistry 279 13004-13010.

Golstein P, Abramow M, Dumont JE \& Beauwens R 1992 The iodide channel of the thyroid: a plasma membrane vesicle study. American Journal of Physiology 263 C590-C597.

Hayden LJ, Shagrin JM \& Young JA 1970 Micropuncture investigation of the anion content of colloid from single rat thyroid follicles. A micromethod for the simultaneous determination of iodide and chloride in nanomole quantities. Pflugers Archives 321 173-186.

Huber G, Derwahl M, Kaempf J, Peter HJ, Gerber H \& Studer H 1990 Generation of intercellular heterogeneity of growth and function in cloned rat thyroid cells (FRTL-5). Endocrinology 126 1639-1645.

Jhiang SM, Cho JY, Ryu KY, DeYoung BR, Smanik PA, McGaughy VR, Fischer AH \& Mazzaferri EL 1998 An immunohistochemical study of $\mathrm{Na}+/ \mathrm{I}-$ symporter in human thyroid tissues and salivary gland tissues. Endocrinology 139 4416-4419.
Kawaoi A, Matsumoto H, Suzuki K \& Moriyama S 1991 Histogenesis of diisopropanolnitrosamine (DIPN)-induced tumors of the rat thyroid gland. Virchows Archive B, Cell Pathology including Molecular Pathology 61 49-56.

Kogai T, Endo T, Saito T, Miyazaki A, Kawaguchi A \& Onaya T 1997 Regulation by thyroid-stimulating hormone of sodium/iodide symporter gene expression and protein levels in FRTL-5 cells. Endocrinology 138 2227-2232.

Nilsson M, Bjorkman U, Ekholm R \& Ericson LE 1992 Polarized efflux of iodide in porcine thyrocytes occurs via a cAMP-regulated iodide channel in the apical plasma membrane. Acta Endocrinologica 126 67-74.

Peter HJ, Gerber H, Studer H \& Smeds S 1985 Pathogenesis of heterogeneity in human multinodular goiter. A study on growth and function of thyroid tissue transplanted onto nude mice. Journal of Clinical Investigation 76 1992-2002.

Royaux IE, Suzuki K, Mori A, Katoh R, Everett LA, Kohn LD \& Green ED 2000 Pendrin, the protein encoded by the Pendred syndrome gene (PDS), is an apical porter of iodide in the thyroid and is regulated by thyroglobulin in FRTL-5 cells. Endocrinology 141 839-845.

Salabe GB, Corvo L \& Lotz H 1996 Thyroglobulin determined in thyroid fine needle aspiration biopsies by radial immunodiffusion and electroimmunodiffusion. European Journal of Clinical Chemistry Clinical Biochemistry 34 43-47.

Smeds S 1972 A microgel electrophoretic analysis of the colloid proteins in single rat thyroid follicles. II. The protein concentration of the colloid single rat thyroid follicles. Endocrinology 91 1300-1306.

Studer H, Peter HJ \& Gerber H 1989 Natural heterogeneity of thyroid cells: the basis for understanding thyroid function and nodular goiter growth. Endocrine Reviews 10 125-135.

Suzuki K, Matsumoto H, Kobayashi M, Kawaoi A, Asayama K \& Moriyama S 1991 Immunohistochemical localization of copper-zinc and manganese superoxide dismutases in diisopropanolnitrosamine-induced rat thyroid lesions. Acta Histochemistry Cytochemistry 24 69-73.

Suzuki K, Kobayashi M \& Kawaoi A 1992 Immunohistochemical demonstration of proliferating cell nuclear antigen in growing cells on formalin-fixed, paraffin-embedded tissue sections. Acta Histochemistry Cytochemistry 25 13-18.

Suzuki K, Kobayashi Y, Katoh R, Kohn LD \& Kawaoi A 1998a Identification of thyroid transcription factor-1 in C cells and parathyroid cells. Endocrinology 139 3014-3017.

Suzuki K, Lavaroni S, Mori A, Ohta M, Saito J, Pietrarelli M, Singer DS, Kimura S, Katoh R, Kawaoi A et al. 19986 Autoregulation of thyroid-specific gene transcription by thyroglobulin. PNAS 95 8251-8256.

Suzuki K, Lavaroni S, Mori A, Okajima F, Kimura S, Katoh R, Kawaoi A \& Kohn LD 1998c Thyroid transcription factor 1 is calcium modulated and coordinately regulates genes involved in calcium homeostasis in C cells. Molecular and Cellular Biology $187410-7422$.

Suzuki K, Lavaroni S, Mori A, Yamamoto K, Yi X, Miyagi E, Katoh R, Kohn LD \& Kawaoi A 1999a Thyroglobulin: a master regulator of follicular function via transcriptional suppression of thyroid specific genes. Acta Histochemistry Cytochemistry 32 111-119.

Suzuki K, Mori A, Lavaroni S, Miyagi E, Ulianich L, Katoh R, Kawaoi A \& Kohn LD 1999 In vivo expression of thyroid transcription factor-1 RNA and its relation to thyroid function and follicular heterogeneity: Identification of follicular thyroglobulin as a feedback suppressor of thyroid transcription factor-1 RNA levels and thyroglobulin synthesis. Thyroid 9 319-331.

Suzuki K, Mori A, Saito J, Moriyama E, Ullianich L \& Kohn LD 1999c Follicular thyroglobulin suppresses iodide uptake by suppressing expression of the sodium/iodide symporter gene. Endocrinology 140 5422-5430. 
Thomas GA, Williams D \& Williams ED 1989 The clonal origin of thyroid nodules and adenomas. American Journal of Pathology 134 141-147.

Ulianich L, Suzuki K, Mori A, Nakazato M, Pietrarelli M, Goldsmith P, Pacifico F, Consiglio E, Formisano S \& Kohn LD 1999 Follicular thyroglobulin (TG) suppression of thyroid-restricted genes involves the apical membrane asialoglycoprotein receptor and TG phosphorylation. Journal of Biological Chemistry 274 25099-25107.

Wollman SH \& Loewenstein JE 1973 Rates of colloid droplet and apical vesicle production and membrane turnover during thyroglobulin secretion and resorption. Endocrinology 93 248-252.

Yamamoto K, Xue Y, Katoh R \& Kawaoi A 1997 Differential immunolocalization of thyroglobulin $(\mathrm{Tg})$ in the follicular epithelium of rat thyroid gland and its kinetics under thyrotropin (TSH) stimulation - A quantitative immunoelectron microscopic analysis using post-embedding immunogold technique-. Acta Histochemistry Cytochemistry 30 147-155.

Yamamoto K, Kato Y, Matsumoto H, Moriyama SI \& Kawaoi A 1988 Inverse correlation between thyroid peroxidase (TPO) and gamma-glutamyl transpeptidase (GGT) activities expressed in diisopropanolnitrosamine (DIPN) induced rat thyroid lesions: an enzyme histochemical study. Acta Histochemistry Cytochemistry 21 455-461.

Yi X, Yamamoto K, Shu L, Katoh R \& Kawaoi A 1997 Effect of Propylthiouracil (PTU) administration on the synthesis and secretion fo thyroglobulin in the rat thyroid gland: a quantitative immunoelectronmicroscopic study using immunogold technique. Endocrine Pathology 8 315-325.

Yoshida A, Sasaki N, Mori A, Taniguchi S, Mitani Y, Ueta Y, Hattori K, Sato R, Hisatome I, Mori T et al. 1997 Different electrophysiological character of I-, ClO4-, and SCN- in the transport by Na+/I- symporter. Biochemical and Biophysical Research Communications 231 731-734.

Yoshida A, Sasaki N, Mori A, Taniguchi S, Ueta Y, Hattori K, Tanaka Y, Igawa O, Tsuboi M, Sugawa H et al. 1998 Differences in the electrophysiological response to I- and the inhibitory anions SCN- and ClO-4, studied in FRTL-5 cells. Biochimica et Biophysica Acta 1414 231-237.

Yoshida A, Taniguchi S, Hisatome I, Royaux IE, Green ED, Kohn LD \& Suzuki K 2002 Pendrin is an iodide-specific apical porter responsible for iodide efflux from thyroid cells. Journal of Clinical Endocrinology and Metabolism 87 3356-3361.

Yoshida A, Hisatome I, Taniguchi S, Sasaki N, Yamamoto Y, Miake J, Fukui H, Shimizu H, Okamura T, Okura T et al. 2004 Mechanism of iodide/chloride exchange by pendrin. Endocrinology 145 4301-4308.

Received in final form 6 February 2006

Accepted 7 February 2006

Made available online as an Accepted Preprint 13 February 2006 